\title{
Energy saving Architecture: Background, Theory and Practice in Kyrgyzstan
}

\author{
Erkin Boronbaev* \\ Kyrgyz State University of Construction, Transportation and Architecture; 720020, 34 b, Maldybaev str., Bishkek, Kyrgyzstan
}

\begin{abstract}
This paper for the first time presents a set of background, theory and practice of energy saving architecture of buildings that allows harmonization of appropriate thermal "behaviour" of the building itself with the energy saving behavioural actions of the people in it depending on yearround and daily dynamics of renewable energy of an environment and incoming solar radiation. Energy saving architecture offers a solution to the two-fold task of saving energy and ensuring acceptable internal conditions due to the beneficial influence of natural processes of the building and human behaviour. It is aimed to provide year-round acceptable parameters for the internal microclimate and sanitary-hygiene conditions and to minimize heating, cooling, and ventilation energy consumption. This paper presents the derivation of the formula on the dimensionless indicator of the building's energy efficient form; its values of the real building forms; examples of solved computational optimization of the location, orientation, and size of the building, and its rooms and thermal envelope components (especially windows and doors). Considerations include issues of minimizing the effect of thermal bridges, especially architectural ones, as well as the structural and operational bridges from the author's classification. The architectural, constructional, and operational practices are demonstrated by: passive gain and prevention of solar heating; heating and cooling by natural ventilation.
\end{abstract}

\section{Background}

This paper for the first time presents a set of background, theory and practice of energy saving architecture of a building that allows harmonization of appropriate thermal behavior of the building itself with the energy saving behavioral actions of the people in it. This "behavior" of the building and behavioral actions of the people depend on year-round and daily dynamics of renewable energy of an environment and incoming solar radiation. A significant reserve of energy saving lies in the development of appropriate architecture of buildings and the behavioral actions of people, and it is possible to utilize a building's energy efficient form and orientation, to take and accumulate heat from solar radiation as much as possible or shield against it, and to adjust energy efficient day and night natural aeration.

As a primary factor, architecture must be adapted to seasonal climate conditions. On the other hand, the daily weather conditions are so diverse and dynamic that maximum support of indoor climate and energy saving requires the participation of people in the building. In 1998, the author first put forward the theoretical idea and term of energy saving architecture [1] and received an acceptance of them at a conference in Prague, Czech and Slovak Federative Republic.
The concept of a single-family residential building was presented, the windows of which "follow" the daily solar geometry and allow implementation of the principle of the building's self-regulation of the thermal regime and indoor microclimate parameters. As a continuation of this approach, the author gave a presentation about the idea of a climate neutral home and its residents at the UN forum in Rotterdam, Netherlands, in 2010. The author hopes that the energy saving architecture of the building, which allows people to carry out daily reductions of greenhouse gases released into the atmosphere, will contribute to restraining planetary climate change $[2,3]$. It is obvious that harmony in the implementation of the above objective and subjective factors allows effective utilization renewable energy of the environment and solar radiation for the appropriate daily use of the building. The total effect of only a few and expensive high-tech "smart buildings" is much less than the effect of numerous and simple low-tech buildings with energy saving architecture and the behavior of its climate change concerned occupants.

\footnotetext{
* Erkin Boronbaev: boronbaev@elcat.kg
} 


\section{Theory}

The author presents the building as an open thermodynamic system with lumped parameters having a thermal envelope with an inhabited volume $V_{e}, \mathrm{M}^{3}$, and an external surface area $A, \mathrm{~m}^{2}$. An elementary change in the mass-average temperature $\Delta \dot{t}_{3},{ }^{\circ} \mathrm{C}$, of a building with $\operatorname{mass} \dot{M}_{i}, \mathrm{~kg}$, and the mass heat capacity $\dot{M}_{3} \dot{C}_{3}$ over a period of time $\Delta \tau$, s, depends, firstly, on the processes of heat and mass transfer with the environment through the indicated surface, and secondly, on the effect of heat gains and losses occurring inside this envelope $\Sigma \Delta Q_{\mathrm{e}}, \mathrm{W}$. Such a system makes it possible to take into account, on the one hand, the heat from heating or cooling the mass of all physical bodies, including the air, which are inside this envelope shell or pass through it, and on the other hand, the release of apparent heat from people, household appliances, equipment, etc. The heat exchange of the building envelope with the environment depends on the difference between the temperatures on its external surfaces $t_{n e}$ and the outside environment $t_{o}$, the heat transfer coefficient $\alpha_{e}, \mathrm{~W} /\left(\mathrm{m}^{2} \cdot{ }^{\circ} \mathrm{C}\right)$, presented as the sum of convective $\alpha_{\kappa}$ and radiant $\alpha_{l}$ components. In practice, instead of $t_{o}$, the outside temperature $t_{e}$ is taken. Accordingly, the total heat transfer in the $\mathrm{j}$ elements of a building's thermal envelope with the environment can be represented as, $\Sigma\left[\dot{a}_{e j} A_{j}\left(\dot{t}_{n e . j}-\dot{t}_{e . j}\right)\right]$, W. While developing the heat balance of the building, it is obtained a simulated mathematical model of the building:

$$
\dot{M}_{3} \dot{c}_{3} \frac{d \dot{t}_{i}}{d \tau}=\Sigma \Delta \dot{Q}_{e} \pm \Sigma\left[\dot{a}_{e j} A_{j}\left(\dot{t}_{n e . j}-\dot{t}_{e . j}\right)\right], \mathrm{W} .
$$

Based on this model, the author concludes that if the mass heat capacity of the building he dates of each thermal enclosure) is significant, the building has a more stable thermal state - more stable parameters of the thermal microclimate. This conclusion becomes the theoretical basis for well-known fundamental proposals of scientists about the need to obtain high thermal stability $[4,5]$ and thermal mass $[6,7]$ for the building and its envelope.

Given that we are interested in the parameters of the internal microclimate (in particular, temperature, relative humidity, and velocity of internal air), the building can also be represented as an open thermodynamic system with lumped parameters on a volume $V_{i}$ and mass $M_{i}$ of renewal internal air, limited by the internal boundary of the thermal envelope. Over a period of time $\Delta \tau$ the change in the mass average temperature $\Delta \dot{t}_{i}$ of internal air with the mass heat capacity $\dot{M}_{i} \dot{c}_{p}$ depends, firstly, on the conditions of unsteady convective heat transfer $\dot{a}_{i k}$ of envelope surfaces (with $t_{\text {in }}$ and $A_{i}$ ), furniture, equipment, etc.; and secondly, on other effects of apparent heat $\Delta \dot{Q}_{i n}$, in particular, air entering and leaving this boundary.

Accordingly, the simulated mathematical model of the building takes the form:

$$
\dot{M}_{i} \dot{c}_{p} \frac{d \dot{t}_{i}}{d \tau}=\Sigma \Delta \dot{Q}_{i n} \pm \Sigma\left[a_{i k} j A_{i j}\left(t_{i j}-t_{i n} j\right)\right], \mathrm{W} .
$$

This model is the theoretical basis of the need to minimize $\dot{M}_{i} \dot{c}_{p} d \dot{t}_{i}$ fluctuations in magnitude, namely, the mass average temperature of internal air as one of the parameters of the room's microclimate needed maximum stability. In practice, by minimizing the sum of the right side of the equation (2), it is possible to realize the author's proposed idea [1] to ensure "self-regulation" of the thermal regime and indoor microclimate parameters of the building (specifically, indoor air temperature $t_{i}$ ).

The left side part $\dot{M}_{i} \dot{c}_{p} d \dot{t}_{i}$ of the equation (2) can be written as $\pm \Delta \dot{Q}$, and then the transformed parts of the right side of this equation represent those components of the building's heat balance that are associated with heat losses (heat transfer through the thermal envelope $\dot{Q}_{o}$, heating or cooling of penetrating air $\dot{Q}_{\beta}$ ) and heat gains (from people, devices, equipment, etc. $\dot{Q}_{\sigma}$, solar radiation $\dot{Q}_{c}$, and microclimate maintenance systems $\dot{Q}_{M}$ ) according to the formula:

$$
Q_{\sigma}+Q_{\mathrm{c}} \pm Q_{\mathrm{B}} \pm Q_{\mathrm{o}} \pm Q_{\mathrm{M}} \pm \Delta Q=0, \mathrm{~W} \cdot \mathrm{h} .
$$

The main task is to minimize $Q_{\mathrm{M}}$ by mutually agreed changes in other components of this equation while ensuring the specified room's microclimate parameters.

As a theoretical basis for the energy saving architecture of the building in equation (3), each component represents as the sum of two interrelated effects: 1) the effect of natural processes; 2) the effect of the influence of human actions. For example, in the cold season, the negative total cooling effect to the building $Q_{b}$ by outside air entering occurs, firstly, due to the natural processes $Q_{\text {.nat }}$ - its penetration through crevices and infiltration through the building's thermal envelope; secondly, because of the human actions $Q_{\text {s.hum }}$ - when opening doors and windows. Accordingly, $Q_{B}=Q_{\text {b.nat }}+Q_{\text {b.hum. }}$. With successful energy saving architecture, the proportion of $Q_{\text {s.hum }}$ is significant. In winter, it is necessary to minimize the natural air exchange in the rooms. So, when there are no people, the air exchange should not be lower than its corresponding norm in order to prevent an increase of humidity of the air and the enclosures' material, and also to ensure the required quality of internal air. In the hot period when $t_{i}<$ $t_{e}$, during day hours intensive natural air exchange should not cause significant heating of the rooms. When $t_{e}<t_{i}$, people can arrange for maximum air exchange by natural airing, taking into account the allowable air velocity in the room, the purity of the outside air, and the level of external noise. Energy saving architecture should also ensure the implementation of energy saving opportunities to reduce $Q_{\mathrm{M}}$ by increasing or decreasing $Q_{o}$ and $Q_{c}$ depending on day hours and seasons, conditions of weather, and climate.

The author proposed the classification of the building's thermal states as three types of thermal regimes: 1) the natural thermal regime, when in equation (3) $Q_{\sigma}=0$ and $Q_{\mathrm{M}}=0$, while the building interacts with the environment's thermal of energy $Q_{b}$, 
$Q_{o}$ and incoming solar radiation $\left.Q_{c} ; 2\right)$ the disturbed natural thermal regime, when in equation (3) $Q_{\mathrm{M}}=0$ and the building is under the influence of $Q_{b}, Q_{o}$ and $Q_{c}$, as well as internal thermal effects $Q_{\sigma} ; 3$ ) artificial thermal regime, when the building is under the influence of thermal effects $Q_{b}, Q_{o}, Q_{c}$ and $Q_{\sigma}$, as well as artificial heating or cooling systems $Q_{\mathrm{M}}$. In all three modes, $\Delta Q$ is present, but in the consideration of the long-term period, it is negligible.

Each of the three thermal regimes is important for the development of energy saving architecture and depends on the building's functional purpose and its use schedule, climate, weather, and other conditions of the building location. Then closer the location to the equator, the greater the influence of $Q_{c}$, and vice versa. Where wind is strong and constant during a cold period, the consideration of $Q_{b}$ is more important. In addition, $Q_{b}$ defines the principal concept of energy saving architecture if night cooling by natural airing the rooms during the hot period is most important. For regions with a cold and humid climate, the consideration of $Q_{o}$ is also important. For the development of energy saving architecture, the selected structures and materials for thermal insulation of the building are important too.

The first type of thermal regime is exist, for example, in a summer home or in a building during the holiday period. when there are no people in them and no internal thermal effects (electrical appliances, heating, cooling and ventilation systems are turned off); the second one when there are people in the building, but these systems do not work; the third one - in the presence of people in the building and during the operation of these systems. A study of the natural thermal regime of a summer home can show that during the coldest period, the temperature of the internal air may drop below the allowable for enclosures preservation [8]. So, the architecture of this summerhouse is required to provide an artificial thermal regime: it is necessary to have automatic preservation space heating system.

A graphical interpretation [9] of equation (3) depending on the year-round change an average daily outdoor temperature $t_{\mathrm{i}},{ }^{\circ} \mathrm{C}$, can be used as a guide for developing energy saving architecture and operation modes of a building. Here, the consumption of artificial energy to maintain the microclimate $Q_{\mathrm{M}}$ is presented as coordinates differences of the lines of total heat gains and losses. One of the main advantages of the graphical interpretation of equation (3) [10] is that the "scissors" of these lines turn out to be closed for the building with almost "zero energy" and to be nearly closed for the passive house.

For the cold period, when $t_{e}<t_{\mathrm{i}}$, the equation (3) can be represented as

$$
Q_{\mathrm{M}}=Q_{\sigma}+Q_{c}-Q_{6}-Q_{o} \pm \Delta Q, \mathrm{~W} \cdot \mathrm{h} .
$$

In order to reduce the energy consumption $Q_{\mathrm{M}}$ for building heating, in particular, it is necessary to minimize $Q_{b}$ and $Q_{o}$. It is known, that for the reference heating period with the duration $\mathbf{Z}$, days, heat loss through the thermal envelope of the building $Q_{o}$ with an average heat transfer coefficient $k_{c p}, \mathrm{~W} /\left(\mathrm{m}^{2} \cdot{ }^{\circ} \mathrm{C}\right)$, (known as $U$-value) and the outer surface area $A, \mathrm{~m}^{2}$, can be calculated according to the formula

$$
Q_{o}=k_{c p} A \Sigma\left[\left(t_{i}-t_{e j}\right) z_{j}\right], W
$$

Minimization task of $Q_{o}$ can be achieved by reducing all the components of the left side of equation (5), except $t_{e}$.

From the standpoint of energy saving, it is advantageous that the architecture of a building incorporates a form that for a given thermal envelope's internal volume $V_{i}$, provides a minimum contact area $A$ with the external environment. Consequently, the energetically ideal geometric model of a building is a sphere.

The author proposes [11] the concept of an energyefficient building form. It allows quantifying the level of energy efficiency regarding the form of a real building with a given volume $V_{i}$ by comparing the total heat loss of a real building $Q$ and a theoretical one $Q_{m}$ in the form of a sphere of the same volume for the compared buildings in the referenced heating period (when it is considered that the heat transfer process is quasistationary) in the equation (3) $\Delta Q=0$. If the compared buildings are of the same function (for example, a residential building with $t_{i}$ ) and are in the same climate conditions, to be considered that $Q_{\sigma}=Q_{\sigma . m}, Q_{\sigma}=Q_{b . m}$, and also $Q_{c}=Q_{c . m}$. Under these conditions, by comparing $Q$ and $Q_{m}$, which have equal average heat transfer coefficients of the theoretical and real buildings $k_{m . c p}=$ $k_{c p}$, we will get:

$$
E_{s}=\frac{\Delta Q_{o}}{Q_{o . m}}=\frac{k_{c p}\left(A-A_{m}\right) \Sigma\left[\left(t_{i}-t_{e j}\right) z_{j}\right]}{k_{m . c p} A_{m} \Sigma\left[\left(t_{i}-t_{e j}\right) z_{j}\right]}=\frac{A-A_{m}}{A_{m}} .
$$

The $E_{s}$ indicator is a quantitative measure of the theoretically possible potential for improving the form of a real building with a given volume relative to the indicators of an ideal building in the form of a sphere of the same volume. It serves as a basis for a wide range of specialists in a simple, clear and practically effective methodology for improving the form of a building in the stages its planning, design, construction, and reconstruction. Based on the idea of energy saving architecture, firstly, the building's location, form, volume, size, and orientation as well as its rooms and enclosures are determined, and secondly, thermal envelope's energy efficient characteristics identified.

A comparison of the $E_{s}$ values of ordinary buildings II, III and IV (Table) with the same volumes of $10,300 \mathrm{~m}^{3}$ (such as the volume of a nine-story concrete panel house) shows that building II with a compact cube form has heat losses through the thermal envelope at $24 \%$ more than the theoretical building I in the form of a sphere. 
Table. $E_{\mathrm{s}}$ values of the theoretical potential for improving the form of buildings II, III and IV of equal volumes relative to the spherical building I of the same volume

\begin{tabular}{|l|l|l|l|ll|}
\hline Building No. & I & II & III & IV & \\
\hline Store & - & 7 & 9 & 5 & \\
\hline Height, $\mathrm{m}$ & 27 & 21,76 & 27 & 15 & \\
\hline $\begin{array}{l}\text { Plan, } \\
\text { (a x B), m }\end{array}$ & $\mathrm{D}=27$ & $21,7 \quad \mathrm{x}$ & $11.2 \quad \mathrm{x}$ & $11.2 \quad \mathrm{x}$ \\
\hline Area, $A, \mathrm{~m}^{2}$ & 2289 & 21,7 & 34.1 & 61.3 & \\
\hline$E_{S}$ & 0 & 0,24 & 3207 & 3548 & \\
\hline
\end{tabular}

In turn, the compact cubic building II has $16 \%$ and $31 \%$ less heat loss than buildings III and IV that are in the forms of rectangular cuboids with comparatively longer plan sides.

From the above it follows that the theoretical basis for the implementation of energy saving architecture is a simulation mathematical model of the building which is converted into equation (3) of the building's heat balance, which is convenient for practical use. The development of energy saving architecture goes through the stage of computational (optional) optimization of the real building's form with a given volume, relative to a theoretical building in the form of a sphere of the same volume. For these purposes, equation (6) was obtained for a dimensionless energy efficiency indicator of the form of a real building, which allows a quantitative assessment of the degree of thermal performance of the form of any building.

\section{Practice in Kyrgyzstan}

About $65 \%$ of Kyrgyzstan's population lives in rural areas in low-rise buildings with a low level of thermal performance and inner microclimate. They often have a $30-60 \%$ potential to reduce energy consumption through appropriate decisions of planning, orientation, construction and thermal insulation.

Energy saving architecture of a residential building [12] designed and implemented in Bishkek, Kyrgyzstan (Fig. 1). The building makes use of a near to compact cube form with Es $=0,32$ and the area of its main windows surpass the standard (dimensions of 1960x1520 $\mathrm{mm}$ ) and orient towards the south. Such an orientation and a special arrangement of wall recesses provides: a) minimization of the heat gain from solar radiation during summer overheating of the building (June, July, August); b) maximum solar heat gain in the main rooms while saving heat energy for heating and reducing the duration of the heating period. In addition, these windows, with opening flaps, allow a night southern breeze coming from the mountains to enter. This architectural solution, reinforced by the presence of a thermal ventilation tower as an extension of the staircase room, as well as a panoramic recreational terrace, allows night-time cooling of rooms by vertical ventilation and long-wave radiation from the sky (through the floor of the indicated terrace).
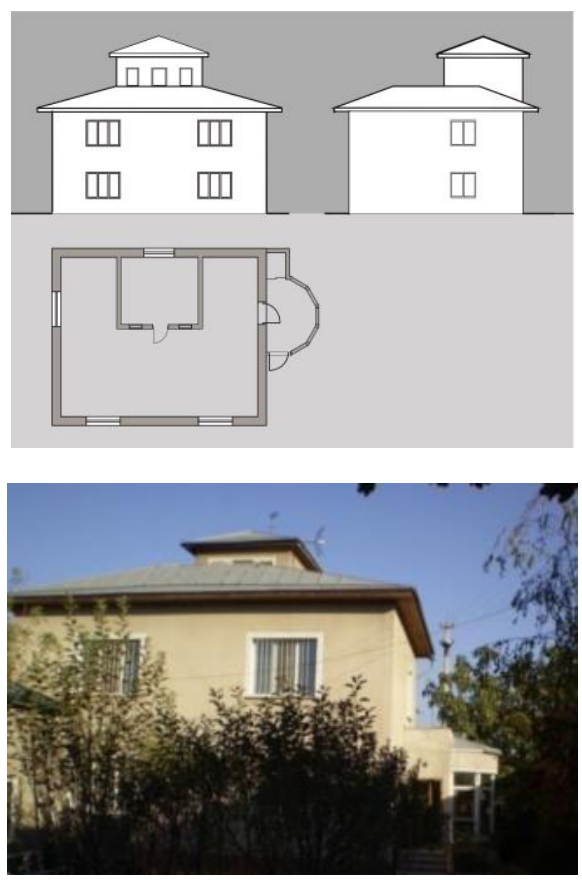

Fig. 1. Energy efficient house with solar heating and night cooling due to an across-vertical airing and long-wave radiation of the sky

Obviously, the building's architecture does not give the maximum cumulative effect without the appropriate behavioral actions of people in the building. Based on obtained experience, taking into account weather conditions as well as thermostatic values of adjusted temperature of the rooms and outside temperature, the house's occupants adequately open and close the casement window and blinds. In practice, these behavioral actions allow the thermostatic valves to turn off the radiators (of low temperature heating system with a constant water temperature in supply pipe $60{ }^{\circ} \mathrm{C}$ with its natural circulation), and during the summer days with a building's overheating periods, air conditioning is not required (because of night cooling a sufficient thermal mass of the rooms by natural ventilation). Energy saving architecture ensures the regulatory level of the thermal regime of the building's thermal performance.

From these positions, the need to adapt the building to the characteristics of the building location should be taken into consideration. Glazing of south faced clay brick wall (Tromb-Michel) of a house in Bishkek [13] allows [according to equation (3)] in the cold period increase $Q_{c}$, decrease $Q_{b}$, and $Q_{o} ;$; and in the summer period, due to covering it with a shading device, reduce $Q_{c}, Q_{o}$ and glare of the sunrays, and the heating of surrounding surfaces and air.

The mountainous territory of Kyrgyzstan (as well as many similar regions in the world, including the territories of Tajikistan, Uzbekistan and China) has not only a wide range of climatic zones but also various levels of seismic danger. Fig. 2 shows a two-story residential building with a typical earthquake resistant reinforced concrete frame. This frame reduces the energy efficiency of the building, since concrete inclusions in the thermal envelope increases heat loss. 


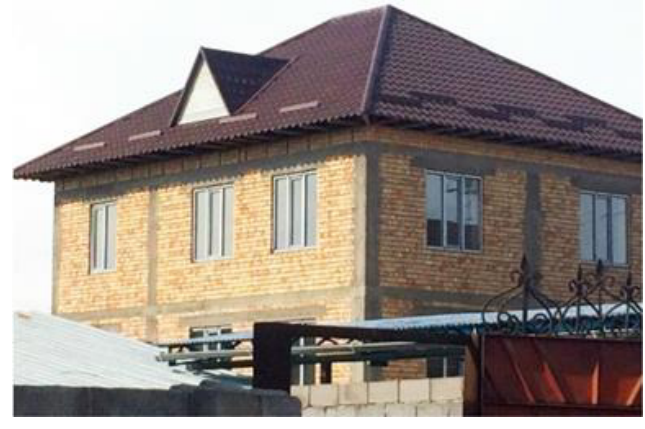

Fig. 2. Two-story brick residential building with anti-seismic reinforced concrete frame, Bishkek

The author theoretically defined and practically classified heat bridges [14] as architectural, structural, and operational. The corner zones of the exterior walls belong to architectural thermal bridges. On the interior surface of these zones, temperature is often below the temperature on the main surface, which required microclimate norms. Such temperatures without sufficient ventilation of the room, cause mold growth (Fig. 3,) leading to a violation of sanitary conditions.

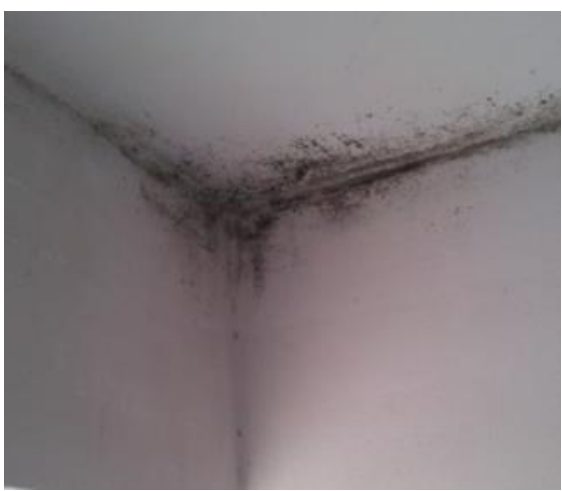

Fig. 3. Mold growth on the corner zones of the exterior walls

Using special field measurement investigations (taken with an infrared thermometer, Fluke 68), the author founded and implemented a rounding of the interior corner of the exterior walls with cement-sand mortar (Fig. 4) which makes increasing the temperature on this zone surface.

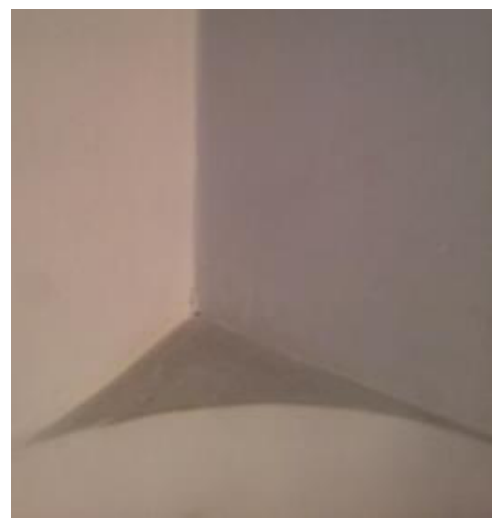

Fig. 4. Rounding of the corner with cement-sand mortar
This rounding reduces the intensity of the heat flux through this zone. Fig. 5 shows that the radius of the rounding can be determined based on the temperature distribution in the corner zone by using the «ArchiCAD $20 »$ tool.

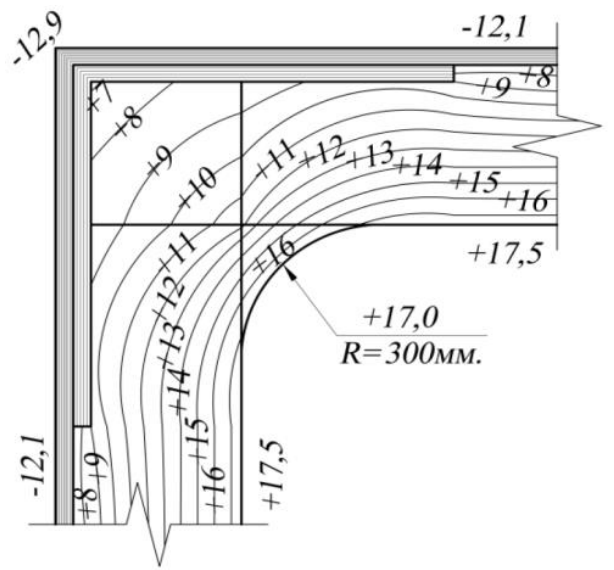

Fig. 5. The definition of the radius of the rounding of the corner with cement-sand mortar based on temperature isolines in the presence of the main layer and an additional layer of external insulation

As you can see, with a $300 \mathrm{~mm}$ rounding radius with the main and additional external thermal insulation of the wall's corner (with seismic concrete corner column on $340 \times 340 \mathrm{~mm}$ ), it is possible to achieve a temperature on its surface up to $17^{\circ} \mathrm{C}$, which is only 0,5 ${ }^{\circ} \mathrm{C}$ lower than the temperature of the main inner surface of the exterior wall with thickness on $380 \mathrm{~mm}$ (when temperature of outside air $-13,3^{\circ} \mathrm{C}$ and of indoor air 20 ${ }^{\circ} \mathrm{C}$ ). Such an architectural solution also significantly improves the interior view of the room.

From the position of setting the required parameters of the internal microclimate at low energy consumption, the author agrees with many architects who prefer buildings with rounded forms. In these two examples, the restaurant (Fig. 6, in the form of a Kyrgyz national yurt with $\left.E_{S}=0,154\right)$ and a hemispherical swimming pool (Fig. 7); both have energy saving advantages.

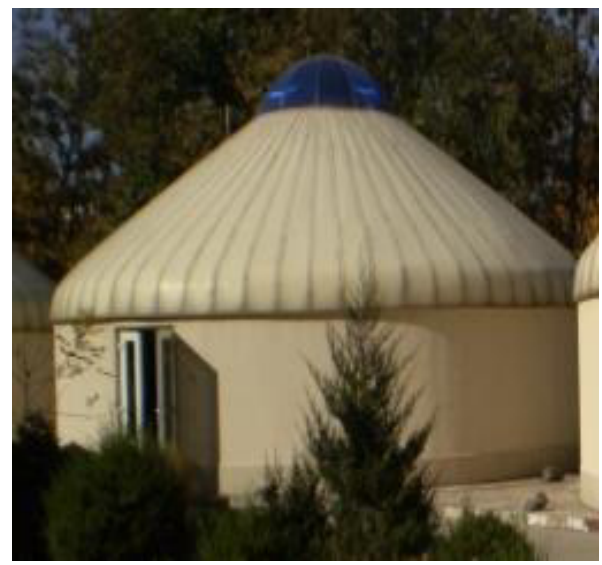

Fig. 6. The restaurant building in the form of a Kyrgyz national yurt in Bishkek 


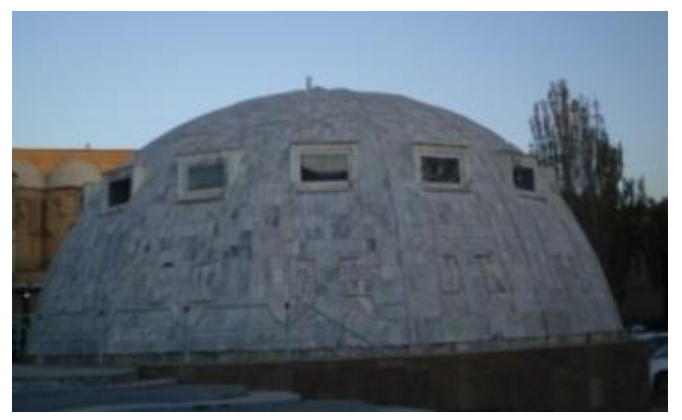

Fig. 7. Hemispherical swimming pool in Bishkek

These advantages arise, firstly, in the relatively small areas of the outer surface of the thermal envelope of buildings; secondly, the small number and negative effect of thermal bridges, especially architectural [14] thermal bridges.

The author's investigations [15] showed that in the cold period the windows on the southern facade of the building near sunny noon act as an element of radiant panel heating due to the significant heating of the glass by solar radiation. Such heating is practically absent from the windows on the eastern and western facade, and the windows on the northern facade are source of cold [15] during cold season.

For regions with cold winters and hot summers, it is necessary to adopt energy saving architecture for the building that minimizes energy consumption by both the heating and the air conditioning systems. On Fig. 8 presented a residential building in Bishkek (with a geographic northern latitude of $42^{\circ} 52^{\prime} 12^{\prime \prime}$ ), which has the main living rooms on the southern facade and do not have windows, but most of the windows with significant areas are located on the eastern and western facades.

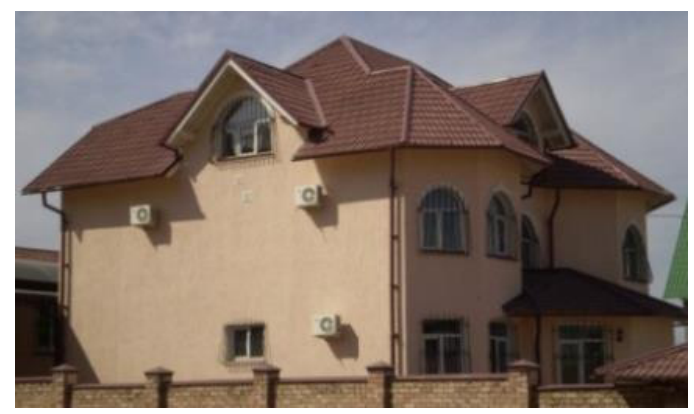

Fig. 8. Two-story house with energetically impractical architecture in Bishkek, Kyrgyzstan

From the viewpoint of energy saving architecture, the placement of windows on the facades should be on the other side. In other words, if developing the energy saving architecture for the climatic conditions of Bishkek, this house could do without these three summer-use air conditioners. Firstly, in the hot summer, windows oriented east and west cause overheating of the rooms. The main reason is that intense direct solar radiation penetrates through these eastern and western facade windows before and after noon when the trajectory of the sun is lower. During the hot summer period, windows located on the southern facade mainly receive oblique sunrays (when trajectory of the sun is high), which causes less heating of the rooms. During the cold period windows on the southern facade, firstly, reduce energy consumption for space heating, and secondly, increase the level of comfortable indoor microclimate. This is because low sunrises fall on these windows from sunrise to sunset in the daytime. It is also important that the energy saving architecture concept is involved in the creation of inexpensive and stationary shading devices for windows on the southern facade for summer conditions, which, on the other hand, do not much reduce the mentioned above heating effect for the cold season. Moreover, with such architecture, having windows orientated to the south with opening frames could allow the implementation of energy-saving behavior of people for significant night cooling of the brick building due to night airing by a cool mountain breeze (as in the building on Fig. 1).

From this point of view, the importance of adopting energy saving architecture becomes greater as the building location approaches the Equator. Fig. 9 presents a house in the Khudjand city, Tajikistan, located at geographic northern latitude $40^{\circ} 16^{\prime} 57^{\prime \prime}$.

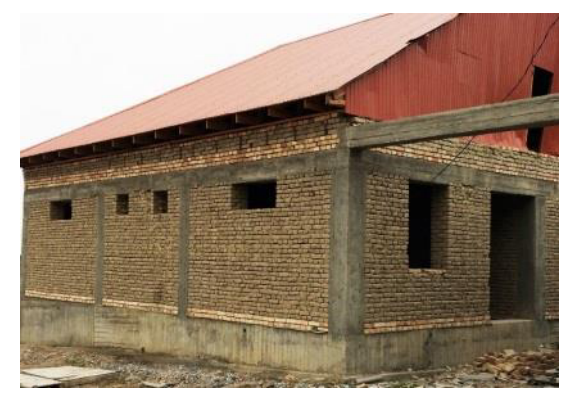

Fig. 9. House with living rooms windows oriented to the south and secondary rooms to the north in Khudjand, Tajikistan

Year-round changes of the daily trajectories of the sun dictate the placement of auxiliary rooms on the north side of the building with small window. Such windows in the cold period do not cause a significant cooling of the rooms [15].

Due to the above reason for the rooms' summer overheating, the residents of a multi-story panel house renovated their apartment: They reduced the area of the glazing facade, oriented to the west, by closing off main parts of its surface with a brick wall (Fig. 10).

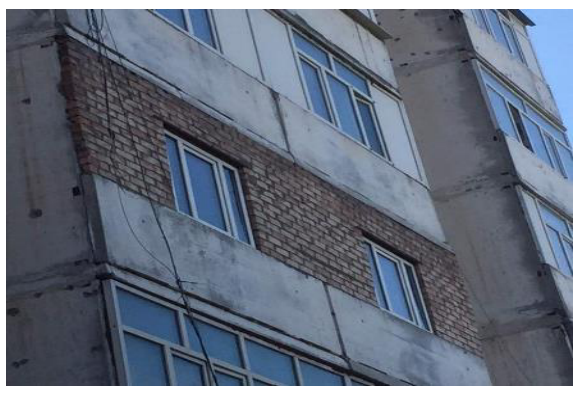

Fig. 10. Renovation against summer overheating by filling part of the glazing on the western facade of a multi-story building in Bishkek 
Such well-known buildings have low thermal performance. In 1996, a similar nine-story building (at the address: Bishkek, micro district Asanbay, 9) was renovated [16] and the thermal insulation was installed on the facades (Fig. 11) with $50 \mathrm{~mm}$ thick non-extruded polystyrene sheets.

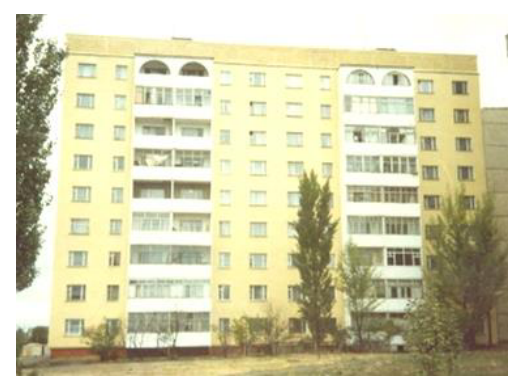

Fig. 11. Renovation by external thermal insulation of the facades of a multi-story building in Bishkek

Due to such an additional layer and cement-sand plaster, the position of the windows on the facade oriented to the south turned out to be more deepened in the thickness of the wall. In the summer period, such a position of the windows causes their substantial shading and improves the internal microclimate, especially during hours around noon. In the cold season, the effect of reducing solar gain is insignificant since lateral window shading occurs in a time nearer to the morning and evening hours when the intensity of direct solar radiation is insignificant.

Fig. 12 presents a representative of clay brick houses at the beginning of XIX century with ordinary architecture for the south region of Kyrgyzstan and the vast territory of Uzbekistan. As you can see, the main windows are located on the southern façade and shaded in summer by nearby planted trees.

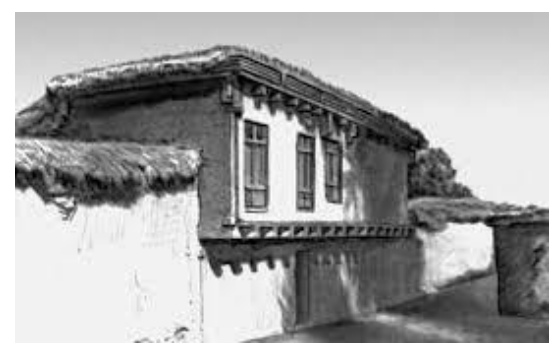

Fig. 12. Representative of clay brick houses at the beginning of XIX century with ordinary architecture for the south region of Kyrgyzstan and the vast territory of Uzbekistan

It is known that in those days both the height and the volume of rooms were small. This helped to reduce heating expenses in the winter. Furthermore, thick (500$600 \mathrm{~mm}$ ) clay brick walls and clay coating provided both acceptable and stable internal microclimate conditions for the cold period as well as pleasant coolness in the hot summer season. The location of the windows on the southern facade surface makes it possible to receive the heat of solar radiation from sunrise to sunset in the cold period. It should be noted here that the same effect is provided by three windows on the southern facade of the house in Fig. 2.

Ancient houses built using clay, wood, and other natural materials (Fig. 12 shows that reeds were used to cover the building) are recyclable and do not contain much embodied energy. Accordingly, historical buildings were much more environmentally friendly and "greener" compared with modern buildings constructed from materials made by energy consuming technologies. On the other hand, a relatively large embodied energy of building's industrial materials indirectly characterizes the measure of level of greenhouse gases released into the atmosphere during their production.

A two-story house [17] in Darmstadt-Kranichstein, Germany, is built according to the Passive House Standard in which most of the windows in the living area are oriented toward the south. The task of optimizing such glazing for the European region has been solved taking into account the total heat input of solar radiation and the embodied energy of the glazing materials and argon and krypton gases.

With the participation of the author, students and residents of the mountain village of Bala Aiylchy $(65 \mathrm{~km}$ from Bishkek, Kyrgyzstan) constructed a straw-bale multifunctional building (Fig. 13) with energy saving architecture [18].
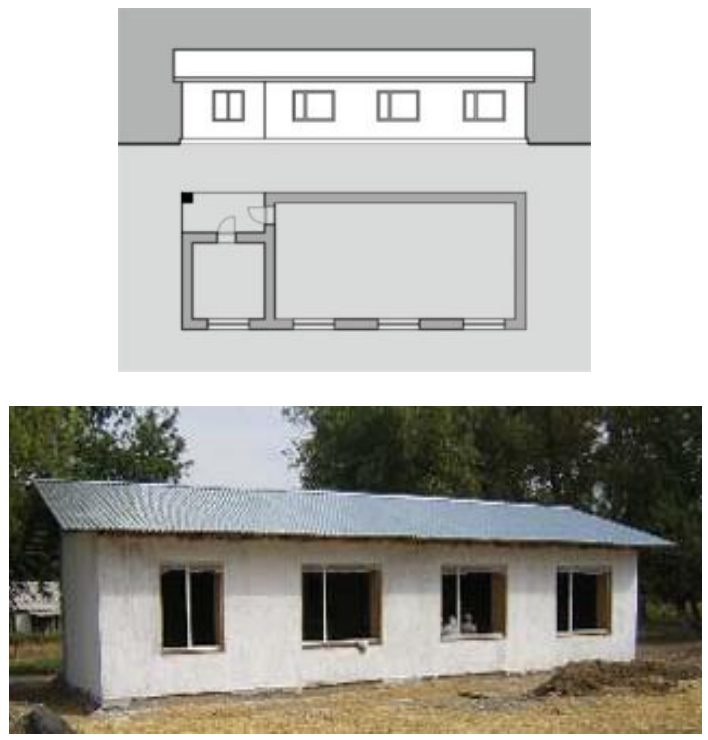

Fig. 13. Multifunctional building made of straw bales in a mountain village with optimized window positions relative to the roof cornice

The building's architecture adopted based on a computer simulation including computational optimization of the components of the equation (3). Firstly, the mutually agreed dimension of the roof overhang $(1000 \mathrm{~mm})$ was determined, and secondly, the corresponding optimal positions of the upper and lower borders of the windows (sill and header heights) on the southern facade, depending on year-round and hourly solar geometry. As a result, it achieved: a) maximum shading of the windows in the hottest summer period; b) significant solar heat gains in the rooms during the winter period since solar radiation from sunrise to sunset 
enters the windows. Acceptable microclimate conditions achieved with the appropriate actions of people by increasing or decreasing natural ventilation by appropriately opening the windows.

For people living in a remote mountainous region with long and harsh winters, but with intense solar radiation, the author proposed a house design [19] with energy saving architecture (Fig.14) without windows on the eastern, western and northern facades. This sufficiently insulated [19, 20, 21] building and side rooms have significant solar heating during the cold period through main and narrow side windows $210 \mathrm{~mm}$ high.

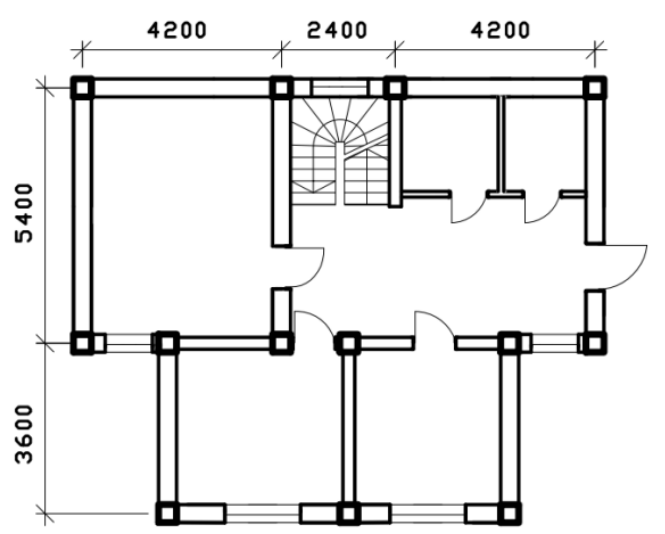

Fig. 14. Residential building plan with energy-saving architecture that provides maximum winter solar heating and prevents summer overheating

The energy saving architecture is useful in regions with strong continental climate eliminates of significant winter cooling and summer overheating of the rooms. During the overheating summer period, residents can carry out night cooling of rooms through natural airing with a mountain breeze by opening windows and special sliding sashes on the staircase.

\section{Conclusions}

The scientific novelty of the article is that it presents the theoretical basis for the development of energy saving architecture based on the three types of year-round building regimes classified by the author. Such architecture is practically realized by solving a double task: 1) to provide appropriate thermal "behavior" of the building, harmonized with objective external and internal thermal influences; and 2) to increase such "behavior" of the building by energy saving behavioral actions of people. Both tasks are solved depending on the year-round and daily dynamics of environmental renewable energy (the thermal potential of the outside air around the building's external surfaces, the sky, and the wind) and the incoming solar radiation. Task 1 involves the selection of the appropriate location of the building (relative to adjacent mountain slopes, base soil, other buildings, and the "wind rose"), form, orientation, size of the building, its premises and enclosures, and especially windows and doors. Task 2 is solved based on purposefully adopted measures that allow people to implement energy-saving behavior depending on the dynamics of weather conditions and thermal processes in the building. It is proposed to create moveable insulation options during winter nights, extra shading, and insulation during summer daytime (for windows when view and daylight are not needed), and manually regulate the intensity of natural ventilation and aeration, and the capacity of heating and cooling devices.

\section{References}

1. Boronbaev E. Applied Optics and Solar Energy. Prague, 1, 296-299 (1998)

2. Smith P. Architecture in a Climate Change (Elsevier Ltd, 2008)

3. Roaf S., Crichton D., Nicol F. Adapting Buildings and Cities for Climate Change (Elsevier Ltd, 2009)

4. Богословский В.Н. Строительная теплофизика (Москва, Высшая школа, 1982)

5. Кувшинов Ю.Я. Теоретические основы обеспечения микроклимата (Москва, АСВ, 2007)

6. Waterfield P. The energy efficient Home (The Crowood Press Ltd, 2006)

7. Norbert L. Heating, Cooling, Lighting: Design methods for architects (John Wiley and Sons, 2001)

8. Боронбаев Э.К., Абдылдаева А.М., Абрамов Б.В., Муханова К.К., Поляков Ю.В. Наука, нов., технол. и иннов. Кыргызстана. 1. 45-48 (2017)

9. Боронбаев Э.К. Извест. вузов. Строит., Новосибирск. 10, 60-64 (2004)

10. Боронбаев Э.К. Объедин. научн. журнал. Москва. 31 (54), 64-67 (2002)

11. Боронбаев Э.К. Пробл. упр. и автом. Бишкек, 3, 449-453 (2000)

12. Боронбаев Э.К. Вестн. КГУСТА, Бишкек. 4, 121130 (2013)

13. Поляков Ю.В., Орозалиев И.М., Боронбаев Э.К., Абдыкалыков А.А., Абдылдаева А.М. Вест. Белгор. гос. техн. унив. 4. 116-120 (2010).

14. Боронбаев Э.К. Вестн. КГУСТА, Бишкек. 3, 130136 (2013)

15. Боронбаев Э.К. Пром. и гражд. строит., Москва. 2, 59-60 (2011)

16. Lorsbach M., Narciss G., Boronbaev E. K. Human Dimensions of Energy Consumption. ACE3. Washington / Berkeley, 8, 8.103-8.112 (1996)

17. Benjamin K. Optimum glazing in the regions of Europe considering the embedded energy (Passivhaus Institut, Report, July 2014)

18. Бинц А., Боронбаев Э.К., Кунц Р., Тохлукова Э.О., Абдылдаева А.М. Вестн. КГУСТА, Бишкек. 1, 75-82 (2004)

19. Боронбаев Э.К., Поляков Ю.В., Бокоева Ж.Б., Санатбекова А.С. Вестн. КГУСТА, Бишкек. 4, 118-124 (2018)

20. Danny Harvey L.D. A Handbook on Low-Energy Buildings and District-Energy Systems (Earthscan, 2007)

21.Земцов В.А., Гагарин В.Г. Архит. и строит., Москва. 5, 147-151 (2009) 